de la más cursi afectación. Un instante en un invernadero: En el invernadero-bailan los colibrís de las catleyas y en el verdoso acero-de las cinnias ovulan las estrellas-y un tulipán de luz pare un lucero.s Con excepción del verso final, contenido e intenso, los cuatro versos restantes hacen pensar en la hora de apogeo de la afectación y cursilería provincianas. Sin embargo el romance, el romance antiguo de motivo popular, es expresado en forma artística for el autor. San Serenín $y$ sus pájaros que es el mejor romance del libro contiene una insignificante historia poéticamente escrita, en que se nota precisamente aquello que escasea tanto en el libro que comentamos: una emoción sincera expresada con fluidez y sencillez.

Pero tales momentos felices no logran desvirtuar la impresión desfavorable que nos produjo la lectura de esta guía. Su autor dice por ahí (pág. 76) «y yo voy a defenderme con mis coplas de abalorio». Esto es exacto, hay muchas cuentas de abalorio en el collar de las poesías del señor Buendía, y esos abalorios no pueden defender a nadie. Creemos que esto se debe a que se toma la labor literaria como una moda en que hay que ajustarse al último patrón, a ese dernier cri poético que en provincias, esto en España y en todas partes, sólo conduce a extravíos del peor gusto.-Abel Valdés $A$.

\section{Mio CiD CAMPEADOR, por Vicente Huidobro.}

Hazaña bautiza a su último libro Vicente Huidobro. ¿Qué es, en suma, una shazaña»? Su mismo creador nos lo explicará:

... una novela épica o una novela que se canta o la exaltación que produce en el poeta una vida superior.

...la novela de un poeta y no la novela de un novelista.

\section{(Nota a la dedicatoria.)}

Por su parte, los editores, bajo la evidente inspiración del poeta, sentencian:

La Hazaña es una especie de novela épica o más bien una serie de tapices heroicos sin más argumento o hilo central que el nombre del mismo personaje que sirve de tema a la obra y los episodios tejidos en torno a la vida de dicho personaje.

(Nota de los editores.)

No estamos precisamente en el reino de la claridad: novela épica, novela de un poeta y no de un novelista, serie de tapices heroicos. No importa. Bastante hace el poeta con crear su obra para que, de adehala, le pidamos que la explique. En el examen del poema, o novela, o del poema-novela, hallaremos elementos suficientes para darnos cuenta de la nueva aventura literaria de Vicente Huidobro. Para que no se dé a la palabra aventura un sentido peyorativo anticipo desde luego que considero esta obra la más lograda y seria de Huidobro. Otra cosa será creer que se trata de una obra maestra como lo aseguran los entusiastas editores (1).

(1) Mio Cid Campeador, por Vicente Huidobro. Compañía Ibero Americana de Publicaciones, Madrid, 1929. 
Maestra por su fuerza lírica, por su fuerza de pasión, por su originalidad de forma y fondo.

\section{(Nota de los editores.)}

¿No sería más digno que los editores se abstuvieran de tales manifestaciones? Más digno de ellos y más digno del poeta. Porque, a continuación, nos dicen cosas tan hiperbólicas que predisponen al lector independiente contra el autor. Por ejemplo:

Episodios cantados a todo pecho y con absoluta libertad, tanta libertad que no han faltado quienes ingenuamente se extrañen de ciertos anacronismos voluntarios que el autor se complace en presentar en sus obras. Muchos, después de Huidobro, han tratado de dar la misma nota y aproximarnos las grandes figuras históricas haciéndolas convivir con el lector, sin lograr manejar el Tiempo y el Espacio con la gracia, vigor y desenvoltura de nuestro poeta.

Al revés de su héroe y ancestro (Huidobro se llama «el último de los descendientes" del $\mathrm{Cid}$ ) que ganaba batallas después de muerto, los libros de Huidobro conquistan discipulos antes de publicarse. ¿No dijo Cansinos Assens en un artículo famoso que el poema Adan de Vicente Huidobro, publicado en 1916, había influido en Los poemas de la serenidad de Ernesto Guzmán, publicados en 1914? ¿Quienes serían, en este caso, los imitadores de Huidobro? Ni Ludwig ni Maurois que han publicado sus libros esenciales antes de 1930 y a quienes Huidobro, sin nombrarlos, hace derivar de Johannes Jorgensen, autor de la Vida de San
Francisco de Asís. Huidobro hace un distingo terminante entre la chazaña», novela épica, y las «vidas noveladas`. ¿Quiénes, pues, serían los discípulos que, sin ser conocida, había hecho la shazaña de Huidobro?

Parecerá que nos detenemos demasiado en los detalles. Es verdad. Pero estos mismos detalles, aparentemente sin importancia, servirán para explicarnos mejor la personalidad del auténtico poeta que hay en Huidobro. No somos de los negadores sistemáticos pero tampoco formamos en la legión de los admiradores incondicionales que traducen su devoción en gestos inefables e interjecciones románticas.

Porque ¿qué sentido tiene llamar a Huidobro, como lo hacen sus editores, "rey de las imágenes» o ciniciador de la más nueva modalidad poéticas? ¿No son estos elogios, por lo excesivos y amplios, expresiones vacías de sentido? Lo de rey de las imágenes tiene una indudable ascendencia norteamericana. Hay en los Estados Unidos reyes del caucho. del tocino, del hierro y del cobre. Transformar a un poeta en rey de las imágenes es trasladar a la poesía, las artes, no siempre bellas, del reclamo industrial. ¿Quién en esta era tan compleja en que simultáneamente mueren y nacen tantas cosas puede precisarnos cuál es sla más nueva modalidad poéticas? Los editores nos dicen hablando de Huidobro:

De él nacieron el creacionismo y el ultraísmo y muchos otros ismos más o menos legítimos que corren por el mundo. 
¿A qué confiar a la autoridad anonima e irresponsable de los editores la responsabilidad de hacer afirmaciones más o menos concluyentes en problemas de crítica literaria? Haber lanzado el creacionismo, o cualquier otro «ismo más o menos legítimo', no significa nada en el haber de un poeta. En cuanto al ultraísmo son varios los que se disputan su paternidad. Es pleito literario que todavía no ha sido fallado. $\mathrm{Y}$ que, por lo demás, carece en absoluto de importancia. Disputar tan puerilmente por un nombre que nada significa revela falta de respeto por las labores de la inteligencia. Porque no son los nombres de escuelas o subescuelas los que hacen brotar como por ensalmo las obras de arte o los poetas sino que, al revés, son los poetas y las obras de arte los que sirven para dar nombre a las escuelas. Los editores de Huidobro, coincidiendo por desgracia con el poeta, destacan hechos que nada significan para su mayor gloria.

Huidobro, como él mismo lo declara, ha llamado a contribución para su shazañas, al Cantar, el Romancero, la Gesta, la historia y su propia inventiva. Veamos con qué pasión toma sobre sí la responsabilidad de dejar claro y resplandeciente el nombre del Cid:

...eso de la afrenta de Corpes es falso, primero porque históricamente sabemos que es falso y segundo porque no se explica que nadie se hubiera atrevido a azotar a las hijas del Cid, ni que éste lo hubiera tolerado y no hubiera tomado mucha mayor venganza que la que reza la leyenda. Yo no veo a $\mathrm{mi}$ abuelito el Cid permitiendo que se azotara a mi tía María y a mi abuelita Cristina sin comerse crucios a sus mariclos. Esto es falso. Yo os lo juro. Si fuera cierto lo sabríamos en la familia y ya veríais cómo yo habría hecho añicos en estas páginas a ese par de infames. El hecho de que apenas me ocupe de ellos os probará que la tal afrenta es una ridícula mentira.

\section{(Nota a la dedicatoria.)}

No vamos a discutirle la lógica al poeta ya que prescindir de ella parece uno de sus lujos. Pero no podemos menos de subrayar el carácter comico que adquiere todo un momento culminante de la leyenda transformado en una cuestión de familia. Otro tanto sucede cuando el poeta nos relata el descubrimiento de su ascendencia heroica:

Me sentí nieto del Cid, me vi sentado en sus rodillas y acariciando esa noble barba tan crecida que nadie se atrevió a tocar jamás.

Otro tanto puede decirse de la dedicatoria del libro en la que el poeta. candidato a la Presidencia de la República en un país de Sud América. se duele de que el título de Marqués de Casa Real esté en manos de quienes sno tienen una gota de la sangre, de su bisabuelo don Vicente García Huidobro y Briand de la Morigandais. Vale también por una dedicatoria la Carta a Mr. Douglas Fairbanks. A ella nos referimos continuamente en nuestras alusiones. $O$ más bien dicho a la nota que la acompaña que es cinco veces más extensa y cien veces más sintomática que la carta misma. El gran animador de 
El Ladrón de Bagdad ha sido quien, con unas palabras, ha despertado en el poeta este apetito de heroísmo que se ha traducido en una resurrección literaria del Cid. Hay trozos que, efectivamente, parecen cortados a la medida de Douglas Fairbanke:

Rodrigo en la fiebre de su angustia sólo piensa en Jimena. Salvarla a ella de las llamas. Que los moros se vayan al diablo por ahora. Ya las pagarán.

De una ventana de arriba oye salir los alaridos desesperados de la nodriza.

Rodrigo se precipita hacia la escalera para subir a las alcobas. La escalera cortada por las llamas se desmorona en carbones ardiendo.

¿Qué hacer? Sale corriendo y vuelve a mirar la siniestra ventana por donde se oyen los gritos.

Hay un árbol, hay un árbol no lejos de la ventana, que pasa más arrıba, casi al techo mismo del castillo.

Está salvada. Bendita sea la mano que plantó tal árbol.

En tres saltos Rodrigo alcanza las ramas. Sube, sube, trepa, trepa. Allá en lo más alto se cuelga de una rama y se deja caer en la ventana.

¡Qué a tiempo llega! Las llamas empiezan a ganar la habitación y entre el fuego y el humo apenas puede ver las manos de la nodriza que se tienden hacia él.

-Allí, allí está. Sálvala.

En un rincón, Jimena, de rodillas, medio asfixiada espera la muerte.

El Campeador corre hacia ella. la coge en sus brazos y se precipita a la ventana.

Jimena le hace un signo: Primero a ella. Salva primero a la nodriza.

Rodrigo, en su angustia, vacila, mira hacia todos lados no sabiendo qué hacer. Rápido coge un cortinaje que empieza a incendiarse. Lo tira, lo desprende de su sostén, lo apaga en el suelo pisoteándolo y amarra en él a la nodriza.

La nodriza, medio muerta, lo mira hacer. Y así en un minuto, él la deja caer por la ventana a sus amigos que aguardan abajo, contemplando la patética escena.

Salvada la nodriza, vuelve a coger a Jimena y con la preciosa carga en los brazos se desliza fuera de la ventana, salta de un saliente a una cornisa, de una cornisa a ur balcón, de la muerte a la vida y con ella en los brazos, liviana a su corazón, cae en tierra lejos de las llamas, fuera de los muros de fuego.

Entre los árboles, bajo la lluvia. frente al incendio, el Campeador mece a Jimena sobre sus rodillas. Jimena convertida en un niño (la muerte vuelve recién nacidos a los que se escapan de sus garras) esconde la cabeza en los brazos del hombre y lora, llora. (Págs. 134-135.)

El trozo, más que la influencia del romancero, el cantar o la gesta, reconoce una evidente ascendencia cinematográfica y norteamericana. Lo que no tiene nada de extraño porque la propensión humorística de Huidobro lo lleva a traducir a párrafos de periodismo actual algunas acciones de su héroe (pág. 90); o a divagar sobre el nombre francés de la manzana (pág. 107); a hacer cantar a los alemanes el Deutschland über alles (pág. 117); o a enviar a nombre del Cid una carta al rey de Granada con los democráticos y económicos «muy señor míos y «saluda a usted ? (págs. 265 y 266); o a decir que el Gid piensa en Cervantes al mirar unos molinos de viento (pág. 304); o a prestar a su héroe arengas napoleónicas (pág. 332); o a convertirlo en el Rockefeller de su época (pág. 358); o a disponer que las huestes 
cristianas eritren triunfalmente a Valencia cantando la difundida y pegajosa canción del maestro Padilla (pág. 383); o a escribir con un relámpago las letras de un afiche (pág. 26); o a entusiasmar a los muchachos para que griten: ¿iViva, hip, hip, hip, hurra! s en homenaje a su jefe (pá. 30); o a sentir un olor a Piel de España y a Chipre de Coty en la habitación de Jimena (pág. 63); o a matar al capitán de los franceses con la palabra de Cambronne ahogada en la garganta (pág. 124); o a suponer que Babieca piafa de alegría al escuchar el canto del poeta (pág. 176); o a contar que el Cid arroja una perra gorda para bombones a un caballero de don Alfonso (pág. 204); o a prometer a los soldados, por boca de su héroe, los versos del Romancero (pág. 412); o a pensar que han puesto salitre, «el maravilloso salitre de Chile,, bajo las plantas de Rodrigo (pág. 27); o entretener al viril mancebo en un boxeo cuerpo a cuerpo rde golpes secos y feroces > con un oso (pág. 50); o a mostrar for una ventana cla nariz de alcuza de una vieja de Valle Inclán (pág. 81); o a poner en labios del Cid un sutil y soberbio retruécano de la frase de Pascal sobre las razones del corazón que la razón no comprende (pág. 84); o a conseguir que la Historia (con mayúscula) retrate al Cid con un kodak (pág. 88); o a dar antes de las batallas chansonettes, burdeos, champagne y Chateau Margaux a los soldados franceses y sus jefes (pág. 123).

Se creerá por la extensa pero incompleta lista de incoherencias, a veces ingeniosas, que hemos agru- pado, que es nuestra intención formar una pequeña antología del disparate. Nada de eso. Estamos en el terreno de los canacronismos volunta:ios» y pecaríamos de ingenuos si nos extrañaramos por ello. En su carta a Douglas Fairbanks desliza Huidobro estas frases luminosas:

Hay muchos poetas que hacen novelas de novelistas. Allá ellos. Yo no participo de ese vicio. Sólo me interesa la poesía y sólo creo en la verdad del poeta.

Es difícil convencerse de que pueda haber otra novela que la del novelista. Huidobro cree en la novela del Poeta (con mayúscula). Es Io que él llama la shazaña*. Pero la verdad es que, después de un viaje laborioso a traves de las cuatrocientas y tantas páginas de su libro, no descubrimos la esencia de la shaza. ñas. No es una novela ni es un poema. A lo que más se acerca es a un escenario cinematográfico y quién sabe si Mr. Douglas Fairbanks sienta al leerla la tentación de darle una realización, genial y ađimirable como suya. Pero acaso estorba al libro. para ser un argumento de cine, su exceso de divagación y de literatura, de retórica en una palabra. Hay escenas como la de persecusión y muerte del moro en el río (pág. 53), la de la muerte del jabalí con una flecha doble que se clava en lodos ojos de la fiera mientras Rodrigo sonríe con sus treintaidós dientes (pág. 57) o los saltos del héroe de ccornisa en cornisa para llegar a la ventana donde está de espaldas su amada Jimena (pág. 69), que tendrían en Douglas Fairbanks el 
único posible animador. La gesta cinematográfica vendría a dar al héroe el vigor que le falta a la shazaña, literaria. El poeta, demasiado seguro de sí mismo, ha subordinado lo esencial a lo accesorio, el héroe al juego retórico.

$\mathrm{Y}$ si nos sorprende con imágenes tan bellas como ésta:

...el volantín que los nifios recogen del cielo, cuando tres niños se hacen cien manos (pág. 32),

en la que hay una comprensión de la línea y el movimiento muy cinematográfica, en cambio se entretiene en jugar con las palabras de la pueril manera con que en esta ocasión lo hace con los moros y las moras:

Mientras va cayendo la tarde $y$ Rodrigo sueña en tragarse a todos los moros del mundo, Jimena sentada en una piedra a los pies de su castillo, está comiendo moras con los labios pintados de negro sonriendo al crepúsculo. (Pág. 46.)

Podrá esto tener la gracia del chiste y el calembour. Pero más adelan. te (pág. 123) el mismo poeta habla de Waterloo no sin advertirnos con delicada generosidad: ‘Felizmente no hubo calembour.>

En todo caso, por graves que seure los reparos que a Mio Cid Campeador pudieran oponerse, hay que reconocer en la chazaña de Huidobro un esfuerzo muy plausible por dar una nota original y fuerte. Como en toda su obra, ha perjudicado al poeta su afán gesticulante de novedad a cualquier precio. No han servido los años para convencer a Huidobro de que nada importa la poesía nueva cuando no es poesía. A él le ha importado, y por desgracia le ha bastado, que sea nueva aunque no sea poesía.

Después de haber agotado todos los cosmopolitismos más o menos espectaculares, hasta llegar a aque1lo, que alguna vez hemos comen$t \approx d o$ risueñamente, de llamarse Vincent Huidobro, se incorpora a la raza con un poema de intento ambicioso y anuncia las shazañas de Hernán Cortés, Cristóbal Colón, Lautaro y acaso Simón Bolívar. Si Vicente Huidobro cumple lo que promete puede llegar el día en que se realice lo que hace doce años auguró Cansinos Assens, su anticipado Juan Bautista: que su paso por España sea lo que fué para el movimiento modernista la estancia de Rubén Darío en la corte. Ya este libro puede hacernos pensar en Vicente Huidobro poeta español. Y con esto quisiéramos decirle el más alto elogio.Roberto Meza Fuentes.

\section{EDUCACION}

\section{LAS ESCUElas NUEVAS INGLESAS. por Margarita Comas.}

Una de las más interesantes publicaciones pedagógicas de España y América es, sin duda, la Revista de Pedagogía de Madrid, dirigida por los más eminentes educadores de la Península y entre cuyos colaboradores cuéntanse casi todos los pedagogos y creadores de escuelas de 